\title{
Determinants of Firm Value in Kenya: Case of Commercial Banks Listed at the Nairobi Securities Exchange
}

\author{
Aloys Ayako ${ }^{1} \&$ Fidelis Wamalwa $^{1}$ \\ ${ }^{1}$ Faculty of Commerce, The Catholic University of Eastern Africa, P.O. Box 62157-00200, Nairobi, Kenya \\ Correspondence: Aloys Ayako, Faculty of Commerce, The Catholic University of Eastern Africa, P.O. Box 62157- \\ 00200, Nairobi, Kenya.
}

Received: June 17, 2015

Accepted: July 1, 2015

Available online: July 7, 2015

doi:10.11114/afa.v1i2.934

URL: http://dx.doi.org/10.11114/afa.v1i2.934

\begin{abstract}
This study analysed the determinants of firm value of commercial banks listed at the Nairobi Securities Exchange (NSE). The analysis was based on secondary panel data over the period 2002 to 2012 . The estimation results of the random effects regression model showed that, though statistically significant $(p<0.05)$, the joint effects of the determinants under the study was low, accounting for about 30 per cent of the variance of the firm value of the listed commercial banks in Kenya. At the individual determinant level, the estimation results were mixed. While we could not reject the null hypotheses that assets, capital structure, cash flows, dividend ratio and intangible had no statistically significant individual effects on the firm value of the listed commercial banks $(\mathrm{p}<0.05)$, we rejected the null hypotheses and concluded that market capitalization had statistically significant individual effects on the firm value of the listed commercial banks $(\mathrm{p}<0.05)$. Given the relatively low joint effects of the determinants under the study, we recommends that further studies should be undertaken to identify and include additional firm specific and both industry level and macroeconomic control variables. The studies should also evaluate the effects of alternative computation of firm value on the model estimation results. The studies may focus on firm value of the listed commercial banks and/or other listed firms in the NSE
\end{abstract}

Keywords: Firm Value, Listed Commercial Banks, Nairobi Security Exchange, Determinants

\section{Introduction}

Since the late 1980s Kenya has witnessed significant growth and sophistication of its capital market (Ayako, et el, 2015). The country's boasts one Nairobi Securities Exchange (NSE) has undergone significant reforms over the last three decades including automation of trading, diversification of listed securities, and dematerialization of stocks) and the development of regulatory and supervisory frameworks. The NSE is one of the fastest growing bourses in the emerging markets and is the largest in East Africa with 50 listed companies, market capitalization of about Kshs. 2,500 billion in market capitalization, about 12 million in traded shares, about 500 million in equity turnover and about Kshs. 2 billion in total daily deals (Ayako et el., Ibid). The growth of the NSE has facilitated mobilization of resources to provide long term capital for financing investments. The government is implementing further reforms to both broaden and deepen of the country's capital market and the performance of the firms listed in the NSE to achieve it long term development goals.

\section{Statement of the Problem}

While the corporate goal of firms listed in the NSE can be assumed to be some variant of the strict shareholder wealth maximization (WWM) model, empirical evidence of the measure of firm value and its determinants is not only scanty but also mixed. Kamunde (2011) analyzed the determinants of firm value of listed telecommunication companies in Kenya. He examined the effects of earnings, operating costs and cost of capital, dividend payout and gearing ratio on firm value. His findings revealed significant negative of dividend payout and gearing ratio on firm value. While the studies by Kamangue and Ngugi (2013) and Samuel et el. (2013) targeted the financial sector, they are limited in scope in terms of both coverage of the industry and determinants. The former study only targeted unit trusts and investigated the influence of board attributes on the firm value. The latter study, on the other hand, only analyzed the effects of dividend policy on firm value of the National Bank Kenya (NBK). Though the findings of these studies were, generally, consistent with the theoretical predictions, they suffered significant methodological limitations. This study builds on the 
past studies to conduct a comprehensive analysis of the determinants of value of the commercial banks listed at the NSE for the period 2002-2012.

\section{Research Questions}

1. What are determinants of firm value of the commercial banks listed at the NSE?

2. What are the conclusion and/or policy implications of the results from (1) above?

\section{Literature Review}

\subsection{Review of Theories}

Baye (2006) defines firm value as the present value (PV) of current expected future cash flows. Symbolically,

$$
\begin{gathered}
\mathrm{PV}(\text { firm })=\mathrm{p}(0)+[\mathrm{p}(1) /(1+\mathrm{i})]+\left[\mathrm{p}(2) /(1+\mathrm{i})^{2}\right]+\left[\mathrm{p}(3) /(1+\mathrm{i})^{3}\right] \ldots+\left[\mathrm{p}(\mathrm{x}) /(1+\mathrm{i})^{\mathrm{T}}\right] \text { where } \\
\mathrm{p}(\mathrm{T})=\text { expected profits at time } \mathrm{T} ; \mathrm{T}=0,1,2, \ldots \mathrm{T} \\
\mathrm{i}=\text { interest rate }
\end{gathered}
$$

Gold (2003) argues that although the equation gives the best estimate of firm value, the firm must have estimates of future profits to use the equation. If the firm does not have future profit estimates, they can determine its value using the constant growth equation:

$$
\begin{gathered}
\mathrm{PV}(\text { firm })=\mathrm{p}(0) *[(1+\mathrm{i}) /(\mathrm{i}-\mathrm{g})] \quad \text { where } \\
\mathrm{p}(0)=\text { profit for the current year } \\
\mathrm{i}=\text { interest rate } \\
\mathrm{g}=\text { growth rate } \\
\mathrm{i}>\mathrm{g}
\end{gathered}
$$

Bay (2006) posits that firm value can also be estimated even after current profits have already been paid out to the shareholders in the form of a dividend using the dividend equation:

$\mathrm{PV}($ ex-dividend-firm $)=\mathrm{p}(0) *[(1+\mathrm{g}) /(\mathrm{i}-\mathrm{g})]$

In this argument, as long as our assumption that the interest rate and growth rate are both constant holds, maximizing profits will also maximize the value of the firm. This leads to the discussion of the determinants of firm value.

According to Thavikulwat (2004), the value of a firm in computerized business gaming simulations can be determined through five different measures: book value, market value, capitalized value, deductive judgment, and adjusted net worth. The firm's book value may be an unreasonable measure of its true value because of the idiosyncrasies of accounting. True market value may be unavailable or unreliable. The capitalized value measure requires an arbitrary parameter, the deductive judgment measure requires subjective judgment, and the adjusted net worth measure requires detailed knowledge of the gaming simulation's model. Developers are in the best position to apply the adjusted net worth measure, so they should code it into their simulation's computer programs.

Hence, determinants of firm value within the banking industry can either be internal or external to the organization in line with the strategic plan of the company, the internal environment and the external environment of the company. Shareholders in companies with high or low payout ratio can reap the benefit of the company's profits when they sell their shareholding. Huselid et el. (2013) cite cash flow, effectiveness and productivity and market value as some of the determinants of a firm value.

According to Shin-Ping and Hui-Ju (2011), shareholder's wealth, growth, dividend-payout, ratio and leverage are key determinants of firm value. This, in effect, delegates the determinants of firm value within the banking industry from the board to the individual shareholder. Payment of a dividend can increase the borrowing requirement, or leverage, of a company.

According to Renee (2005) determinants of firm value within the banking industry include market price, capital structure, dividend ratio because of the critical position they hold in shaping the activities and potentials of the firm with regard to the various stakeholders within the banking industry. Higher dividend payout ratios lead to a lower retained earnings and capital gains, and vice versa, leaving shareholders wealth unaffected. According to Business Directory (2013), enterprise value is the measure of a company's value, often used as an alternative to straightforward market capitalization. Firms may maintain target dividend payout ratio and adjust their determinants of firm value within the banking industry to this target as well as pursue a stable determinants of firm value within the banking industry and gradual increase dividends given the target payout ratio as a way of dealing with the firm value in line with (Brav et al., 2005).

A study conducted by Michaely and Roberts (2007) using data from the UK, found that since dividends have an effect on stock prices and company's future growth, anything that affects the dividend pay-out ratio within the banking 
industry automatically has an effect on the firm value of banks. Critical identification and analysis of the determinants of a firm's value forms the basis for appropriate actions by the management. This may be the reason as to why Abdulrahman (2007) argues that corporate management needs to consider various determinants before taking the decision on the how and when of dividend payout.

While some studies have highlighted the possible effect of past dividends on future earnings, growth of shareholder value and growth potential of the company, others focused on profitability of firms, leveraging among others as determinants of firm value within the banking industry (Mancinelli \& Ozkan, 2006), no study directly gives an in-depth analysis of all the determinants of firm value within the banking industry in the Kenyan market.

A study by Huselid, et el. (1997) found that the key determinants of firm value include assets, cash flow, relative worth and intangible assets such as corporate image/reputation and human resource. The firm value within the banking industry is therefore pegged on critical issues foretasted which may in turn depend on whether the bank is local of international, the region of operation, capital structure, dividend pay-out ratio just to mention but a few. This calls for a brief description of the Kenyan Commercial banking industry.

\subsection{Review of Empirical Evidence}

The widely used empirical framework for measuring firm value is Ohlson's residual income valuation (RIV) model $(1995,2000)$. Residual Income (RI) is the income generated by a firm after accounting for the true cost of capital while Residual Income Valuation (RIV) is an approach to equity valuation that formally accounts for the cost of equity capital. In this case, residual refers to an excess of any opportunity costs measured relative to the book value of the Shareholders' equity. The theory is founded on the assumption that investors require a rate of return from their equity contribution to reward them for their opportunity cost and risk taken by investing.

Consistent with Ohlson's information dynamics, Dechow et el. (1999) found that residual income follows a mean reverting process and that the rate of mean reversion is systematically associated with firm characteristics suggested by accounting and economic analysis. The rate of mean reversion was decreasing in the quality of earnings, increasing in the dividend payout ratio and correlated across firms in the same industry.

Based on the findings of their study, Dechow et el. (Ibid.) concluded that Ohlson's formulation of the residual income valuation model provides a parsimonious framework for incorporating information in earnings, book value and earnings forecasts in empirical research. They also illustrated how many of the valuation relations implicit in past empirical research can be considered as special cases of Ohlson's model and that past earnings and book value convey relatively little information about firm value beyond that reflected in analysts' forecasts of next year's earnings.

Thus, for calculation of residual income, the cost of equity is typically calculated and the currency charge obtained using the formula stated below:

\section{Equity Charge = Equity Capital $\mathrm{x}$ Cost of Equity, and}

Residual income $=$ Net Income - Equity Charge.

This gives the company's valuation as the sum of its book value and the present value of its expected future residual income, discounted at the cost of equity, $r$, as shown below (Dechow et el., 1999).

$$
V_{0}=B V_{0}+\sum_{t=1}^{\infty} \frac{R I_{t}}{(1+r)^{t}}
$$

This however, assumes that the company achieves maturity, or constant growth. The corresponding terminal value can therefore be obtained by assuming the long-run, constant growth $g$ from year $m$, (Dechow, Hutton \& Sloan, 1999) as

$$
T_{m}=\frac{R I_{m}}{(r-g)}
$$

This according to Dechow et el. (1999), gives the RI valuation as:

$$
V_{0}=B V_{0}+\sum_{t=1}^{m-1} \frac{R I_{t}}{(1+r)^{t}}+\frac{T_{m}}{(1+r)^{m-1}}
$$

In the studies on the hedging activities of 119 U.S. oil and gas producers from 1998 to 2001 and evaluated their effect on firm value by Yanbo Jin \& Philippe Jorion (2006). Theories of hedging based on market imperfections implied that 
hedging would increase the firm's market value (MV). To test the hypothesis, they collected detailed information on the extent of hedging and on the valuation of oil and gas reserves. They verified that hedging reduced the firm's stock price sensitivity to oil and gas prices. Contrary to previous studies, however, they found that hedging did not seem to affect MVs for that industry.

Gary et el. (2006) analyzing a panel of U.S. public firms during 1990s, they found that corporate venture capital was associated with the creation of firm value-measured as firm's Tobin's q -but that the relationship was conditional on both sector-specific and firm-specific factors. In particular, the positive relationship between corporate venture capital (CVC) and firm value creation was greatest within the devices, semiconductor, and computer sectors. Moreover, the contribution of corporate venture capital investment to firm value was greater when firms explicitly pursued CVC to harness entrepreneurial inventions. They concluded that in those industries where entrepreneurial ventures were an important source of innovations, corporate venture capital can be a vital part of a firm's innovation toolkit.

Using longitudinal data from the year 2004 to 2007 in Korea, Hyang et el. (2012) found that foreign block shareholders and foreign outside directors respectively provide expertise and independent monitoring over management. Foreign blockholders' management control via board membership is likely to mitigate leverage of value enhancement when foreign outside directors represent private interests of foreign block holders. The moderating effect is also supported since foreign ownership concentration has an inverted U-shaped relationship with value enhancement leading to the conclusion that board independence reinforces the positive impact of foreign outside directors on firm value.

The empirical findings of Noor and Ayoib (2009) revealed that corporate governance mechanisms do have an influence on firm value in Malaysia. The findings showed that although board size and leadership structure affect the firm value for all companies however, not all elements of governance mechanisms are significant, and the effects differ between family-businesses and non-family businesses. An empirical study conducted by Qi and Toyohiko (2005) showed that banks which do not monitor their client firms and are unlikely to push the managers of the firms to take efficient actions on maximizing firm value.

Anup et el. (2010), tested the influence of debt-equity structure on the value of shares given different sizes, industries and growth opportunities with the companies incorporated in Dhaka Stock Exchange (DSE) and Chittagong Stock Exchange (CSE) of Bangladesh. For the robustness of the analysis samples were drawn from the four most dominant sectors of industry i.e. engineering, food \& allied, fuel \& power, and chemical \& pharmaceutical to provide a comparative analysis. A significant positively correlated association was evident from the empirical findings when stratified by industry.

In yet another empirical study by Dalbor, et el. (2007) after controlling for size and risk, found that there was a positive relationship with long-term debt and the value of the firm. This implies that while Return on Assets (ROE) is negatively related to firm value, capital expenditures are not. Emily Zhan (2007), in their article, explored empirically the cross-sectional relation between firm value and the use of property insurance in a sample of 663 unlisted firms in Norway. Using industry adjusted return on assets as a proxy for firm value, their paper documented that the positive relation between firm value and property insurance held for firms with above average financial performance and relatively high leverage( measured as long term debt scaled by total assets) in their sample.

Samuel, et el. (2012), undertook a study to provide evidence on the impact of capital structure on a firm's value. The analysis was implemented on all the 34 companies quoted on the Ghana Stock Exchange (GSE) for the year ended $31^{\text {st }}$ December 2010. The ordinary least squares method of regression was employed in carrying out the analysis. The result of the study revealed that in an emerging economy like Ghana, equity capital was a component of capital structure and was relevant to the value of a firm, and Long-term-debt was also found to be the major determinant of a firm's value.

Kamangue and Ngugi, (2013) conducted a study aimed to investigate the influence of board attributes on the firm value of firms with focus on the unit trusts in Kenya. The study adopted a descriptive research design. A multivariate regression model was applied to determine the relative importance of each of the four variables with respect to the influence of board attributes on firm value. The study found out that majority of the respondents agreed to a great extent that the size of the board had a material impact on the quality of corporate governance and that monitoring expenses and poor communication in a larger board had been seen as a reason for the support of small board size. Samuel et el. (2013) conducted a study to determine the effects of dividend policy on the market share value in the banking industry in Kenya using National Bank Kenya (NBK) as case for the study. The study applied an explanatory research design covering a proportionate sample of 100 shareholders drawn from a target population of 47,000 shareholders of the National Bank of Kenya. Data was collected using a structured questionnaire. Both descriptive and inferential statistics were used to analyze data. The hypotheses were tested by use of Pearson's Moment Correlation. With a response rate of $68 \%$, the study established that NBK had a dividend policy as confirmed by $91 \%$ of the respondents. The study established a significant and positive correlation $(0.850)$ between dividend payout and market share value, with a $\mathrm{P}$-value of 0.000 . 
There was also a positive correlation (0.299) between dividend growth rate and market value of shares with a p-value of 0.013; hence establishing a significant relationship between variables. There was a positive correlation (0.502) between regularity of dividend declaration and market share value with a P-value was 0.000 . Dividend policy had a significant effect on the market share value.

Kamunde (2011) conducted analyzed the determinants of firm value of listed telecommunication companies in Kenya. He analyzed the effects of earnings, operating costs and cost of capital, dividend payout and gearing ratio on firm value. His findings revealed significant negative of dividend payout and gearing ratio on firm value.

Clearly, while internationally empirical literature on the determinants of firm value is abounding, locally it is scanty. Specifically, there are very limited empirical studies have been conducted on the determinants of firm value within the banking industry in Kenya, offering a clear gap that this study intends.

\section{Methodology}

\subsection{Research Design}

This study adopted an explanatory non-experimental research design to investigate the factors influencing the performance of firms listed at the Nairobi Securities Exchange, Kenya. Explanatory research seeks to establish causal relationship between variables (Saunders et al., 2009 \& Robson 2002). According to Kerlinger and Lee (2000) an explanatory non-experimental research design is appropriate where the researcher is attempting to explain how the phenomenon operates by identifying the underlying factors that produce change in it in which case there is no manipulation of the independent variable.

\subsection{Empirical Model}

The following Random Effects panel regression model was specified;

$$
\begin{aligned}
& \quad \mathrm{Y}_{\mathrm{it}}=\beta_{0}+\beta_{1} \mathrm{x}_{1 \mathrm{it}}+\beta_{2} \mathrm{x}_{2 \mathrm{it}+}+\beta_{3} \mathrm{x}_{3 \mathrm{it}}+\beta_{4} \mathrm{x}_{4 \mathrm{it}}+\beta_{5} \mathrm{x}_{5 \mathrm{it}}+\beta_{6} \mathrm{x}_{6}+\beta_{7} \mathrm{x}_{7 \mathrm{it}}+\beta_{8} \mathrm{x}_{8 \mathrm{it}}+\varepsilon_{\mathrm{it}} \text { where; } \\
& \mathrm{Y}_{\mathrm{it}}=\text { Value of firm } \mathrm{i} \text { at time } \mathrm{t} \\
& \mathrm{X}_{1 \mathrm{it}}=\text { Assets of firm i at time } \mathrm{t} \\
& \mathrm{X}_{2 \mathrm{it}}=\text { Capital structure of firm i at time } \mathrm{t} \\
& \mathrm{X}_{3 \mathrm{it}}=\text { Cash flow of firm i at time } \mathrm{t} \\
& \mathrm{X}_{4 \mathrm{it}}=\text { Dividend ratio of firm i at time } \mathrm{t} \\
& \mathrm{X}_{5 \mathrm{it}}=\text { Intangible assets of firm i at time } \mathrm{t} \\
& \mathrm{X}_{6 \mathrm{it}}=\text { Market capitalization of firm i at time } \mathrm{t} \\
& \mathrm{X}_{7 \mathrm{it}}=\text { External environment of firm i at time } \mathrm{t} \\
& \mathrm{X}_{8 \mathrm{it}}=\text { Strategic plan of firm i at time } \mathrm{t} \\
& \varepsilon_{\mathrm{it}}=\mathrm{v}_{\mathrm{it}}+\mathrm{u}_{\mathrm{it}} \text { composite error term }
\end{aligned}
$$

$\mathrm{V}_{\mathrm{it}}$ = Between-firm time-varying unobserved random error term (IID random effects); $\operatorname{Cov}\left(\mathrm{X}_{\mathrm{it}}, \mathrm{v}_{\mathrm{it})}=0\right.$

$\mathrm{u}_{\mathrm{it}}=$ Within-firm time-varying unobserved (idiosyncratic) random error term (it is assumed to fulfill all the assumptions for standard OLS error terms i.e. $\mathrm{u}_{\mathrm{it}}$ is IID).

The hypotheses formulated eight null hypotheses stated thus;

H1: B1 =0 (i.e. Assets have no statistically significant effect on firm value)

H2: B2 $=0$ (i.e. Capital structure has no statistically significant effect on firm value)

H3: B3=0 (i.e. Cash flow has no statistically significant effect on firm value)

H4: B4=0 (i.e. Dividend payout has no statistically significant effect on firm value) 
H5: B5=0 (i.e. Intangible assets have no statistically significant effect on firm value)

H6: B6=0 (i.e. Market capitalization has no statistically significant effect on firm value)

H7: B7=0 (i.e. External environment has no statistically significant effect on firm value)

H8: B8=0 (i.e. Strategic plan has no statistically significant effect on firm value)

\subsection{Data Collection}

The population under study consisted of all the commercial banks listed in the Nairobi Stock Exchange. Although there are 46 commercial banks in Kenya only eleven are listed at the Nairobi Stock Exchange (see Annex I). Given the population size we conducted a census survey in which all the eleven listed firms were studied. The study was based on annual secondary data available from the Capital Markets Authority (CMA). The data on assets, capital structure, cash flow, dividend ratio, intangible assets and market capitalization and firm value were obtained directly or indirectly from various documents such as the strategic plans, cash flow statements, income statements and balance sheets of the individual banks.

The data for the period 2002-2012 is summarized in Annex II. The 10 year period of the study that was considered long enough for trend analysis and identification of the traits of various determinants of the firm value. Owing to challenges in getting complete information on all the listed commercial banks over the past ten years, some extrapolation of the data was necessary. Finally, the nature of the data in this study was panel in nature.

\subsection{Operationalisation of Variables}

Assets were measured by total assets as reflected in the Balance sheet of the respective Banks from the NSE. Dividend payout was measured by the dividend ratio as given by dividends paid out against net income. Intangible assets were picked from the balance sheet, while cash flows were obtained from the cash flow statements. Market capitalization was measured by number of outstanding shares for each bank at the end of each year multiplied by the share price. Finally, firm value was estimated using Ohlson's Residual Income Valuation (RIV) model.

\subsection{Data Analysis}

Being interval in nature, the data was analyzed using descriptive statistics, correlation analysis, and panel multiple regression analysis. Given that classical panel regression model methodology was adopted for this study a set of other classical parametric assumptions/characteristics of the data were performed to ensure its suitability for the regression analysis. To confirm the other parametric nature of the data, we tested for normality, multicollinearity, heteroscedacity and autocorrelation. We also tested for the RE specification using the Hausman test. The estimation of the chosen fixed or random effects models will be based on STATA 11.0 software.

\section{Discussion of Empirical Results}

\subsection{Diagnostic Tests of Parametric Data}

\subsubsection{Test for Normality of residuals}

The analysis for normality of the residuals were conducted using both the histogram and one-sample Kolmogorov-Smirnov test. The results of both analysis confirmed that the residuals were normally distributed.

The histogram followed a bell-like distribution and we could not reject the null hypothesis at $\mathrm{p}<0.05$ (see Annex III and Annex IV).

\subsubsection{Test for Multicollinearity}

To test for multicollinearity the study adopted the variance inflation factors and the tolerance levels. Variance Inflation Factor (VIF) and Tolerance are indicators of Multicollinearity. Computationally, it is defined as the reciprocal of tolerance: $1 /\left(1-R^{2}\right)$. In most cases researchers desire low values of VIF since higher values of VIF are deemed to adversely affect the results from regression analysis. VIF indicates the magnitude of the inflation in the standard errors associated with a particular beta weight that is due to Multicollinearity. Annex IV indicates the VIF and Tolerance levels for the variables used in the study. The VIF values presented in the table indicates that the data does not suffer from Multicollinearity since the values are less than 10 as it is recommended that the VIF values should not been in excess of 10 otherwise they will be considered to be multicollinear.

\subsubsection{Testing For Heteroscedasticity}

Heteroscedasticity test was run in order to test whether the error terms are correlated across observation in the data using Modified Wald Test. The null hypothesis is that the data does not suffer from Heteroskedasticity (i.e. constant variance). The null hypothesis was acceptedat a critical $\mathrm{p}$ value of 0.05 since the reported value was 0.0067 which is 
less than the critical value.

\subsubsection{Test Serial Correlation}

The study used the Wooldridge test for autocorrelation. The null hypothesis of this test was that there was no first order autocorrelation in the data. The computed F statistic value was 36.612 with an associated p-value of 0.6438 and 0.0003 showing presence of statistically significant autocorrelation in the panel dataset. The study corrected for this violation of classical linear regression model assumption by using standardized variables.

\subsubsection{Hausman Test}

The Hausman test basically tested whether the unique errors $(u i)$ are correlated with the regressors, and the null hypothesis was that they are not. Annex V illustrates the results of the Hausman test. The results show that the chi-squared value was 10.52 with an associated p-value of 0.1045 . This therefore implies that the null hypothesis of the appropriate model being fixed effects is rejected and thus the preferred model to be adopted is the random effects model.

\subsection{Regression Results}

Based on the results of Hausman test the study estimated the random effects model. Two determinants, namely, strategic and external environment were dropped from the estimation as they didn't among the listed commercial banks and over time. The results of the random effects regression model estimation are presented in Table 3. As shown, R-squared was 0.135 suggesting that the factors under study accounted for $13.5 \%$ of the variance in firm value. Thus, the factors studied in this study do not account for much of the variance in firm value.

Table 1. Regression Results

\begin{tabular}{lllll}
\hline & Coefficient & Std. Error & z-Statistic & Prob. \\
\hline Constant & -13.827 & 9.970 & -1.39 & 0.164 \\
Assets & 0.337 & 0.301 & 1.12 & 0.263 \\
Capital structure & 2.329 & 2.294 & 1.02 & 0.310 \\
Cash flow & 0.012 & 0.088 & 0.13 & 0.894 \\
Dividend ratio & 0.305 & 0.174 & 1.76 & 0.079 \\
Intangible assets & -0.735 & 0.092 & -0.80 & 0.422 \\
Market capitalisation & 0.252 & 0.047 & 5.38 & 0.000 \\
& & & & 34.46 \\
Number of obs. & 95 & Wald chi ${ }^{2}(6)$ & & 0.000 \\
R-squared within & 0.2726 & Prob>chi2 & & 0.3677 \\
R-squared between & 0.5183 & Sigma_u & & 0.6066 \\
R-squared overall & 0.3070 & Sigma_e & & \\
Rho (fraction of variance due & 0.2687 & & & \\
to u_i) & & & \\
\hline
\end{tabular}

The results show that the joint effect of the six determinants accounted for about 30 per cent of the value of the commercial banks listed at the NSE. This implies that about 70 per cent of the value of these firms is accounted for by other determinants. However, the Wald chi2 of 34.46 was statistically significant $(\mathrm{p}<0.01)$. Hence we rejected the null hypothesis that the joint effect of the determinants on the value of the listed commercial banks was zero or purely random. Although all the determinants had theoretically expected signs, not all had statistically significant individual (partial) effects on the firm value of the firms. Empirical results of the tests of the null hypotheses of the individual effects of the determinants at $\mathrm{p}<0.05$ is summarized in Table 3.

Table 3. Empirical Results Tests of Hypotheses

\begin{tabular}{ll}
\hline Determinant & Decision \\
\hline Assets & Accept H1 \\
Capital Structure & Accept H2 \\
Cash Flow & Accept H3 \\
Dividend Pay Out & Accept H4 \\
Intangible Assets & Accept H5 \\
Market Capitalization & Reject H6 \\
\hline
\end{tabular}

The results show that all but the null hypothesis on market capitalization was rejected at $\mathrm{p}<0.01$. This determinant had statistically significant positive effect on the value of the listed commercial banks. Hence, the finding of the study reaffirms the critical role of market capitalization on firm value enhancement. 
The null hypotheses on assets, capital structure, cash flow, dividend ratio and intangible assets could not be rejected at $\mathrm{p}<0.05$. The finding with respect to the null hypothesis on capital structure seem consistent with the seminal proposition by Modigliani and Miller (in Bay, 2006) proposition of irrelevance of capital structure on firm value under perfect capital market conditions. The results contradicted the findings of the study by Samuel et el. (2013) that dividend policy is an important determinant of the market share value in the banking industry in Kenya. The study established a significant and positive correlation (0.850) between dividend payout and market share value, with a P-value of 0.000 .

The mixed and rather disappointing findings of this study was attributed to both the exclusion of key firm specific, industry level and macroeconomic control variables and weaknesses in the financial management practices in the listed commercial banks in Kenya. By focusing on only six firm specific variables, the study excluded firm specific control variables like firm size, ownership status (i.e. wholly local, wholly foreign or mixed ownership, and extent of government participation), and governance. The study did not include such industry level control variables like market structure/market power and shifts in regulatory regime. The study did not also include such key macroeconomic control variables as economic growth, inflation and exchange rate, all of which of which have important moderating impact on the firm value of the listed commercial banks in Kenya. The exclusion of these key control variables not only explain the low overall explanatory performance of the estimated model but also complicates the accuracy of the interpretations of the estimated coefficients.

The non-rejection of the null hypotheses of most of the determinants in the study was also attributed to possible weaknesses in the financial management of the listed commercial banks in the country. The non- statistically significant partial effect of both assets and intangible assets could be explained by under-utilization of types of assets. These assets should be fully utilized to enhance the firm value. The finding of non-statistically significant relationship between capital structure and firm value of the listed commercial could point to lack of an optimal mix of debt and equity in the financing of these firms. The finding of a non-statistically significant relationship between cash flow and firm value implies lack of good cash flow management strategies geared towards firm value enhancement. Finally, the result of non-statistically significant relationship between dividend ratio and firm value of the listed commercial banks suggests lack of optimal dividend ratio.

\subsection{Conclusions}

Six firm specific variables, namely, assets, capital structure, cash flow, dividend payout ratio, intangible assets and market capitalization determinants accounted for only about 30 per cent of the total variance of firm value of the commercial banks listed at the NSE. The rather disappointing results were attributed to both the exclusion of key variables and financial management weaknesses in the listed commercial banks firm. By focusing on only six firm specific variables, the study excluded firm specific control variables like firm size, ownership status (i.e. wholly local, wholly foreign or mixed ownership, and extent of government participation), and governance. The study did not also include such industry level control variables like market structure/market power and shifts in regulatory regime. Finally, the study did not include such key macroeconomic control variables as economic growth, inflation and exchange rate, all of which of which have important moderating impact on the firm value of the listed commercial banks in Kenya. The exclusion of these key control variables not only explain the low overall explanatory performance of the estimated model but also complicates the accuracy of the interpretations of the estimated coefficients. Consequently, there is a need for further comprehensive studies to integrate the set of control variables, which will also facilitate accurate interpretation of the estimated coefficients.

The possible financial management weaknesses in the listed commercial banks that could have contributed to disappointing results of this study include possible under-utilization of assets and intangible assets, lack of optimal mix of debt and equity in financing firm capital, improper management of cash flows and sub-optimal dividend ratio. It is therefore recommended that the management of the listed commercial should review and correct their financial management practices and realign them to value enhancement. Consequently, there is a need for the listed commercial banks to review their financial management practices to attain optimal firm value.

Finally, the results of the study reaffirmed the practical strategic role of market capitalization in enhancing firm value, implying that the listed commercial banks should also employ strategies that will increase their market capitalization.

\section{References}

Abdulrahman, A. A. (2007). Determinants of firm value within the banking industry and payout ratio: evidence from the Kuala Lumpur stock exchange, The Journal of Risk Finance, 8(4), 349-363. http://dx.doi.org/10.1108/15265940710777306

Anup, C., \& Suman, P. C. (2010), Impact of capital structure on firm's value: Evidence from Bangladesh Business and Economic Horizons, 3(3), 111-122

Ayako, A., Musyoki, D., \& Murungi, S. (2015). Post-Merger and Acquisitions Performance of Commercial Banks Listed at 
the Nairobi Securities Exchange, Research Journal of Finance and Accounting, 6(10), 65-78.

Baker, M., \& Jeffrey, W. (2004). Catering Theory of Dividends, Journal of Finance, 59, 1125-1165. banking industry: evidence from Italian firms, European Journal of Finance, 12(3), 265-382. http://dx.doi.org/10.1111/j.1540-6261.2004.00658.x

Baye, M. R. (2006). Managerial Economics \& Business Strategy, 5th Ed, McGraw Hill, 16-19.

Brav, A., Graham, J., Harvey, C., \& Michaely, R. (2005). Payout policy in the 21st century, Journal of Financial Economics, 77, 83-527.

Brealey, M., Myers, S., \& Allen, F. (2005). Principals of Corporate Finance. 8th Ed. McGraw Hill/Irwin, Compensation in Taiwan, Management Research Review, 34(3), 252-265

Dalbor, M. C., Lee, S., \& Upneja, A. (2007). An Investigation of Long-term Debt and Firm Value

Dechow, P. M., Hutton, A. P., \& Sloan, R. G. (1999). An empirical assessment of the residual income valuation model. Journal of Accounting and Economics, 26, 1-34. USA: Elsevier.

Dickens, R., Casey, K., \& Newman, J. (2002). Bank determinants of firm value within the banking industry: explanatory factors", Quarterly Journal of Business \& Economics, 41, 3-12.

Emily, Z. (2007). Does Property Insurance Increase Firm Value? Norwegian Management School of BI

Gary, D., \& Michael, J. L. (2006), When does corporate venture capital investment create firm value? Journal of Business Venturing, 21,753-772

Gold, S. (2003). The design of a business simulation using a system-dynamics-based approach. Developments in Business Simulation \& Experiential Learning, 30, 243a-243i. https://www.nse.co.ke/listed-companies/list.html

Huselid, M. A., Jackson, S. E., \& Schuler, R. S. (1997). Technical and Strategic Human Resources Management Effectiveness as Determinants of Firm Performance", Academy of Management journal, 40(1), 171-188.

Hyang, M. C., Wonsik S., \& Sang, K. M. (2012). Foreign board membership and firm value in Korea", Management Decision, 50 (2), 20 -233.in the Lodging Industry, in Joseph S. Chen (ed.) 3 (Advances in Hospitality and Leisure.

Kamangue, C. W., \& Ngugi, J. K. (2013). The influence of board attributes on firm value: A case study of the unit trusts in Kenya, European Journal of Management Sciences and Economics, 1(2), 58-69.

Kamunde, J. N. (2011). The determinants of firm value in the telecommunication sector in Kenya. Nairobi: Nairobi University.

Kerlinger, F. N., \& Lee, H. B. (2000). Foundations of behavioral research (4th ed.). Fort Worth, TX: Harcourt.

Leary, M., \& Michaely, R. (2009). Why firms smooth dividends: empirical Evidence', working paper, Cornell University. New York: Ithaca.

Lintner, J. (1956). Distribution of income of corporations among dividends, retained earnings and taxes, American Economic Review, 46, 97-113.

Mancinelli, M., \& Ozkan, A. (2006). Ownership structure and determinants of firm value.

Michaely, R., \& Roberts, M. (2007). 'Dividend smoothing, agency costs, and information asymmetry: lessons from determinants of firm value within the banking industry', working paper, Cornell University. New York: Ithaca.

Noor, A. A., \& Ayoib, C. A. (2009). Family Business, Board Dynamics and Firm Value, Journal of Financial Reporting and Accounting, 7(1), 53-74

Ohlson, J. A. (1995). Earnings, Book Values and Dividends in Equity Valuation”, Contemporary Accounting Research, 11 (Spring), 1995.

Ohlson, J. A. (2000). Residual Income Valuation: The Problems. Available at SSRN: http://ssrn.com/abstract=218748 or http://dx.doi.org/10.2139/ssrn.218748.

Qi, L., \& Toyohiko, H. (2005). Bank relations, cash holdings, and firm value: evidence from Japan, Management Research News, 28(4), 61-73.

Renee, B. A., \& Mehran, H. (2005).Corporate Performance, Board Structure and its Determinants in the Banking Industry, Federal Reserve Bank of New York

Robson, C. (2002). Real World Research: A Resource for Social Scientist and practioners, Research oxford Blackwell.

Samuel, O., Mokaya, D., Nyang'ara, M., \& Lillian, T. J. (2013), the Effect of Dividend Policy on Market Share Value in the Banking Industry; the Case of National Bank of Kenya. International Journal of Arts and Commerce, 2(2), 
February 2013

Saunders, M., Lewis, P., \& Thornhill, A. (2009).Research methods for business students $\left(5^{\text {th }}\right.$ ed) Italy: Prentice Hall.

Shing-P., L., \& Hui-Ju, C. (2011). Corporate Governance and Firm Value as Determinants of CEO

Tajirian, A. (1997). Determinants of firm value within the banking industry. Available online from

http//:www.morevalue.com

Thavikulwat, P. (2004). Determining the Value of a Firm, Developments in Business Simulation and Experiential Learning, 31(3), Emerald Group Publishing Limited, 195-204.

Yanbo, J., \& Philippe, J. (2006), Firm Value and Hedging: Evidence from U.S. Oil and Gas Producers. The Journal of Finance, 61(2), 893-919. http://dx.doi.org/10.1111/j.1540-6261.2006.00858.x

\section{ANNEX I: BIOGRAPHIES OF AUTHORS}

1. Aloys Ayako is an Associate Professor of Economics at the Catholic University of Eastern Africa (CUEA). He holds a PhD and Masters of Political Economy (MAPE) degrees from Boston University in the USA and Masters of Economics degree from the University of Nairobi (UON) in Kenya. He has over thirty years of teaching, supervision of $\mathrm{PhD}$ and Masters degrees' theses and research projects and research experience. He has published widely in peer reviewed journals.

2. Fidelis Wamalwa is a Finance Officer at the Catholic University of Eastern Africa (CUEA). She holds Masters of Business Administration (MBA) degree. She is planning to pursue PhD studies in Finance in the near future.

ANNEX II: LIST OF COMMERCIAL BANKS LISTED AT THE NAIROBI SECURITIES EXCHANGE

1 Barclays Bank Limited

2 CFC Stanbic Holdings Limited

3 I \& M Holdings Limited

4 Diamond Trust Bank Kenya Limited

5 Housing Finance Co. of Kenya (HFCK) Limited

6 Kenya Commercial Bank (KCB) Limited

7 National Bank of Kenya (NBK) Limited

8 NIC Bank Limited

9 Standard Chartered Bank Limited

10 Equity Bank Limited

11 The Co-operative Bank of Kenya Limited

ANNEX III: SECONDARY DATA FOR COMMERCIAL BANKS LISTED AT NSE

\begin{tabular}{lllllllllll}
\hline Year & Bank & Value & Assets & Capital Structure & Cash Flow & DPS & Intangible assets & Market capitalisation & External & Strategic \\
\hline 2002 & Barclays & 98.5 & 85914 & 80.21 & 51423 & 3 & 614 & 18238851 & 1 & 1 \\
2003 & Barclays & 280 & 96914 & 81.24 & 14575 & 3 & 245 & 57031128 & 1 & 1 \\
2004 & Barclays & 200 & 110083 & 85.21 & 45112 & 3 & 1265 & $40,736,520$ & 1 & 1 \\
2005 & Barclays & 232 & 104522 & 84.52 & 18177 & 3 & 1710 & 53364841.2 & 1 & 1 \\
2006 & Barclays & 77 & 117722 & 81.41 & 5081 & 3 & 1250 & 104557068 & 1 & 1 \\
2007 & Barclays & 74 & 157656 & 83.14 & 21876 & 1.65 & 368 & 1245668 & 1 & 1 \\
2008 & Barclays & 78 & 168510 & 87.86 & 48044 & 2 & 546 & 1545444 & 1 & 1 \\
2009 & Barclays & 92 & 164875 & 85.32 & 12151 & 2.5 & 686 & 14121155 & 1 \\
2010 & Barclays & 76 & 172415 & 81.75 & 8640 & 1.36 & 3448 & 47115445 & 1 & 1 \\
2011 & Barclays & 81 & 167305 & 82.53 & 10416 & 1.5 & 3364 & 97455620 & 1 \\
2012 & Barclays & 90 & 185102 & 84.02 & 9809 & 1 & 3452 & 41221154 & 1 & 1 \\
\hline
\end{tabular}




\begin{tabular}{|c|c|c|c|c|c|c|c|c|c|c|}
\hline 2002 & $\mathrm{CFC}$ & 9.2 & 85914 & 80.21 & 51423 & 1 & 614 & 1104000 & 1 & 1 \\
\hline 2003 & $\mathrm{CFC}$ & 33 & 96914 & 81.24 & 14575 & 2 & 245 & 3960000 & 1 & 1 \\
\hline 2004 & $\mathrm{CFC}$ & 58 & 110083 & 85.21 & 45112 & 1 & 1265 & 10022400 & 1 & 1 \\
\hline 2005 & $\mathrm{CFC}$ & 76.5 & 114522 & 82.52 & 18177 & 3 & 1719 & 11934000 & 1 & 1 \\
\hline 2006 & $\mathrm{CFC}$ & 89 & 217722 & 81.41 & 5081 & 2 & 1350 & 13884000 & 1 & 1 \\
\hline 2007 & $\mathrm{CFC}$ & 78 & 157615 & 83.14 & 21876 & 3 & 468 & 1245668 & 1 & 1 \\
\hline 2008 & $\mathrm{CFC}$ & 69 & 169610 & 87.87 & 48046 & 2.1 & 5410 & 1545444 & 1 & 1 \\
\hline 2009 & $\mathrm{CFC}$ & 78 & 144875 & 75.32 & 22851 & 2.5 & 1686 & 14121155 & 1 & 1 \\
\hline 2010 & $\mathrm{CFC}$ & 74 & 171415 & 80.75 & 8651 & 1.4 & 3218 & 47115445 & 1 & 1 \\
\hline 2011 & $\mathrm{CFC}$ & 75 & 167312 & 82.44 & 21416 & 1.2 & 4264 & 97455620 & 1 & 1 \\
\hline 2012 & $\mathrm{CFC}$ & 69 & 122502 & 84.12 & 1909 & 1 & 3652 & 41221154 & 1 & 1 \\
\hline 2006 & EQT & 139 & 96914 & 81.24 & 14575 & 2 & 245 & 12588472.45 & 1 & 1 \\
\hline 2007 & EQT & 142 & 110083 & 85.21 & 45112 & 1 & 1265 & 14121155 & 1 & 1 \\
\hline 2008 & EQT & 139 & 114522 & 82.52 & 18177 & 3 & 1719 & 47115445 & 1 & 1 \\
\hline 2009 & EQT & 140 & 217722 & 81.41 & 5081 & 2 & 1350 & 97455620 & 1 & 1 \\
\hline 2010 & EQT & 125 & 157615 & 83.14 & 21876 & 3 & 468 & 41221154 & 1 & 1 \\
\hline 2011 & EQT & 98 & 169610 & 87.87 & 48046 & 2.1 & 5410 & 104557068 & 1 & 1 \\
\hline 2012 & EQT & 99 & 110083 & 85.21 & 45112 & 3 & 1265 & 1245668 & 1 & 1 \\
\hline 2002 & DTB & 10 & 104522 & 84.52 & 18177 & 3 & 1710 & 795000 & 1 & 1 \\
\hline 2003 & DTB & 28 & 117722 & 81.41 & 5081 & 3 & 1250 & 2782500 & 1 & 1 \\
\hline 2004 & DTB & 28 & 157656 & 83.14 & 21876 & 1.65 & 368 & 2782500 & 1 & 1 \\
\hline 2005 & DTB & 32.5 & 168510 & 87.86 & 48044 & 2 & 546 & 4037109.375 & 1 & 1 \\
\hline 2006 & DTB & 72.5 & 164875 & 85.32 & 12151 & 2.5 & 686 & 10131591.74 & 1 & 1 \\
\hline 2007 & DTB & 45 & 172415 & 81.75 & 8640 & 1.36 & 3448 & 14121155 & 1 & 1 \\
\hline 2008 & DTB & 96 & 167305 & 82.53 & 10416 & 1.5 & 3364 & 47115445 & 1 & 1 \\
\hline 2009 & DTB & 104 & 185102 & 84.02 & 9809 & 1 & 3452 & 97455620 & 1 & 1 \\
\hline 2010 & DTB & 101 & 85914 & 80.21 & 51423 & 1 & 614 & 41221154 & 1 & 1 \\
\hline 2011 & DTB & 98 & 96914 & 81.24 & 14575 & 2 & 245 & 104557068 & 1 & 1 \\
\hline 2012 & DTB & 95 & 110083 & 85.21 & 45112 & 1 & 1265 & 1245668 & 1 & 1 \\
\hline 2002 & $\mathrm{HF}$ & 5.2 & 114522 & 82.52 & 18177 & 3 & 1719 & 598000 & 1 & 1 \\
\hline 2003 & $\mathrm{HF}$ & 12.05 & 217722 & 81.41 & 5081 & 2 & 1350 & 1385750 & 1 & 1 \\
\hline 2004 & $\mathrm{HF}$ & 8.5 & 157615 & 83.14 & 21876 & 3 & 468 & 977500 & 1 & 1 \\
\hline 2005 & $\mathrm{HF}$ & 13.95 & 169610 & 87.87 & 48046 & 2.1 & 5410 & 1604250 & 1 & 1 \\
\hline 2006 & $\mathrm{HF}$ & 48 & 144875 & 75.32 & 22851 & 2.5 & 1686 & 5520000 & 1 & 1 \\
\hline 2007 & $\mathrm{HF}$ & 80 & 171415 & 80.75 & 8651 & 1.4 & 3218 & 97455620 & 1 & 1 \\
\hline 2008 & $\mathrm{HF}$ & 55 & 167312 & 82.44 & 21416 & 1.2 & 4264 & 41221154 & 1 & 1 \\
\hline 2009 & $\mathrm{HF}$ & 46 & 122502 & 84.12 & 1909 & 1 & 3652 & 1104000 & 1 & 1 \\
\hline 2010 & $\mathrm{HF}$ & 39 & 172415 & 81.75 & 8640 & 1.36 & 3448 & 3960000 & 1 & 1 \\
\hline 2011 & $\mathrm{HF}$ & 27 & 167305 & 82.53 & 10416 & 1.5 & 3364 & 10022400 & 1 & 1 \\
\hline 2012 & $\mathrm{HF}$ & 45 & 185102 & 84.02 & 9809 & 1 & 3452 & 12451155 & 1 & 1 \\
\hline 2002 & $\mathrm{KCB}$ & 17 & 85914 & 80.21 & 51423 & 1 & 614 & 2543200 & 1 & 1 \\
\hline 2003 & $\mathrm{KCB}$ & 54 & 96914 & 81.24 & 14575 & 2 & 245 & 8078400 & 1 & 1 \\
\hline 2004 & $\mathrm{KCB}$ & 64 & 110083 & 85.21 & 45112 & 1 & 1265 & 12774400 & 1 & 1 \\
\hline 2005 & $\mathrm{KCB}$ & 113 & 110083 & 85.21 & 45112 & 3 & 1265 & 22554800 & 1 & 1 \\
\hline
\end{tabular}




\begin{tabular}{|c|c|c|c|c|c|c|c|c|c|c|}
\hline 2006 & $\mathrm{KCB}$ & 241 & 104522 & 84.52 & 18177 & 3 & 1710 & 48103600 & 1 & 1 \\
\hline 2007 & $\mathrm{KCB}$ & 250 & 117722 & 81.41 & 5081 & 3 & 1250 & 3960000 & 1 & 1 \\
\hline 2008 & $\mathrm{KCB}$ & 219 & 157656 & 83.14 & 21876 & 1.65 & 368 & 10022400 & 1 & 1 \\
\hline 2009 & $\mathrm{KCB}$ & 274 & 168510 & 87.86 & 48044 & 2 & 546 & 11934000 & 1 & 1 \\
\hline 2010 & $\mathrm{KCB}$ & 119 & 164875 & 85.32 & 12151 & 2.5 & 686 & 13884000 & 1 & 1 \\
\hline 2011 & $\mathrm{KCB}$ & 204 & 172415 & 81.75 & 8640 & 1.36 & 3448 & 1245668 & 1 & 1 \\
\hline 2012 & $\mathrm{KCB}$ & 201 & 167305 & 82.53 & 10416 & 1.5 & 3364 & 1451225 & 1 & 1 \\
\hline 2002 & NBK & 3.65 & 185102 & 84.02 & 9809 & 1 & 3452 & 730000 & 1 & 1 \\
\hline 2003 & NBK & 13.35 & 85914 & 80.21 & 51423 & 1 & 614 & 2670000 & 1 & 1 \\
\hline 2004 & NBK & 18.9 & 96914 & 81.24 & 14575 & 2 & 245 & 3780000 & 1 & 1 \\
\hline 2005 & NBK & 28.75 & 110083 & 85.21 & 45112 & 1 & 1265 & 5750000 & 1 & 1 \\
\hline 2006 & NBK & 58 & 114522 & 82.52 & 18177 & 3 & 1719 & 11600000 & 1 & 1 \\
\hline 2007 & NBK & 45 & 217722 & 81.41 & 5081 & 2 & 1350 & 1245668 & 1 & 1 \\
\hline 2008 & NBK & 55 & 157615 & 83.14 & 21876 & 3 & 468 & 1545444 & 1 & 1 \\
\hline 2009 & NBK & 42 & 169610 & 87.87 & 48046 & 2.1 & 5410 & 14121155 & 1 & 1 \\
\hline 2010 & NBK & 36 & 144875 & 75.32 & 22851 & 2.5 & 1686 & 47115445 & 1 & 1 \\
\hline 2011 & NBK & 65 & 171415 & 80.75 & 8651 & 1.4 & 3218 & 97455620 & 1 & 1 \\
\hline 2012 & NBK & 61 & 167312 & 82.44 & 21416 & 1.2 & 4264 & 41221154 & 1 & 1 \\
\hline 2002 & NIC & 18.55 & 122502 & 84.12 & 1909 & 1 & 3652 & 1528789.926 & 1 & 1 \\
\hline 2003 & NIC & 45.5 & 172415 & 81.75 & 8640 & 1.36 & 3448 & 3749862.082 & 1 & 1 \\
\hline 2004 & NIC & 50 & 167305 & 82.53 & 10416 & 1.5 & 3364 & 4120727.563 & 1 & 1 \\
\hline 2005 & NIC & 51 & 185102 & 84.02 & 9809 & 1 & 3452 & 4203142.114 & 1 & 1 \\
\hline 2006 & NIC & 102 & 85914 & 80.21 & 51423 & 1 & 614 & 8406284.228 & 1 & 1 \\
\hline 2007 & NIC & 98 & 96914 & 81.24 & 14575 & 2 & 245 & 1245668 & 1 & 1 \\
\hline 2008 & NIC & 110 & 110083 & 85.21 & 45112 & 1 & 1265 & 1545444 & 1 & 1 \\
\hline 2009 & NIC & 124 & 164875 & 85.32 & 12151 & 2.5 & 686 & 14121155 & 1 & 1 \\
\hline 2010 & NIC & 112 & 172415 & 81.75 & 8640 & 1.36 & 3448 & 47115445 & 1 & 1 \\
\hline 2011 & NIC & 96 & 167305 & 82.53 & 10416 & 1.5 & 3364 & 97455620 & 1 & 1 \\
\hline 2012 & NIC & 101 & 185102 & 84.02 & 9809 & 1 & 3452 & 41221154 & 1 & 1 \\
\hline 2002 & $\mathrm{SCB}$ & 58.5 & 85914 & 80.21 & 51423 & 1 & 614 & 14463742.64 & 1 & 1 \\
\hline 2003 & $\mathrm{SCB}$ & 191 & 96914 & 81.24 & 14575 & 2 & 245 & 47223501.62 & 1 & 1 \\
\hline 2004 & $\mathrm{SCB}$ & 122 & 110083 & 85.21 & 45112 & 1 & 1265 & 36498080.1 & 1 & 1 \\
\hline 2005 & $\mathrm{SCB}$ & 140 & 114522 & 82.52 & 18177 & 3 & 1719 & 38075493.4 & 1 & 1 \\
\hline 2006 & $\mathrm{SCB}$ & 205 & 217722 & 81.41 & 5081 & 2 & 1350 & 55753401.05 & 1 & 1 \\
\hline 2007 & $\mathrm{SCB}$ & 210 & 157615 & 83.14 & 21876 & 3 & 468 & 1245668 & 1 & 1 \\
\hline 2008 & $\mathrm{SCB}$ & 215 & 169610 & 87.87 & 48046 & 2.1 & 5410 & 1545444 & 1 & 1 \\
\hline 2009 & $\mathrm{SCB}$ & 209 & 144875 & 75.32 & 22851 & 2.5 & 1686 & 14121155 & 1 & 1 \\
\hline 2010 & $\mathrm{SCB}$ & 123 & 171415 & 80.75 & 8651 & 1.4 & 3218 & 47115445 & 1 & 1 \\
\hline 2011 & $\mathrm{SCB}$ & 148 & 167312 & 82.44 & 21416 & 1.2 & 4264 & 97455620 & 1 & 1 \\
\hline 2012 & $\mathrm{SCB}$ & 204 & 122502 & 84.12 & 1909 & 1 & 3652 & 41221154 & 1 & 1 \\
\hline
\end{tabular}


ANNEX IV: HISTOGRAM OF ERROR RESIDUALS

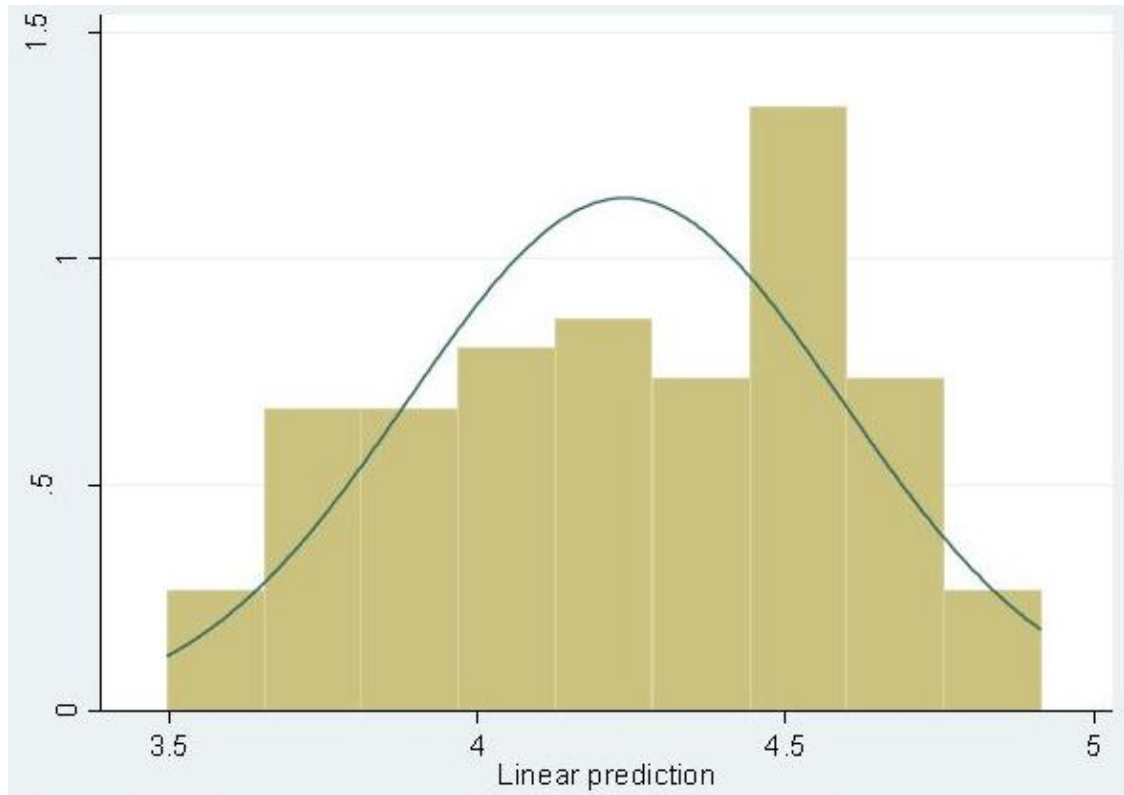

ANNEX V: ONE-SAMPLE KOLMOROV-SMIRNOV TEST

\begin{tabular}{|c|c|c|c|c|c|c|c|c|c|}
\hline & & Value & Assets & $\begin{array}{l}\text { Capital } \\
\text { Structure }\end{array}$ & $\begin{array}{l}\text { Cash } \\
\text { Flow }\end{array}$ & DPS & $\begin{array}{l}\text { Intangible } \\
\text { assets }\end{array}$ & $\begin{array}{l}\text { Market } \\
\text { capitalization }\end{array}$ & Residual \\
\hline \multicolumn{2}{|l|}{$\mathrm{N}$} & 95 & 95 & 95 & 95 & 95 & 95 & 95 & 95 \\
\hline Normal & Mean & 94.47 & 143715.40 & 82.85 & 22254.92 & 1.88 & 2009.19 & 26571675.56 & 0.00 \\
\hline Parameters ${ }^{a b}$ & Std. Dev & 66.77 & 36422.37 & 2.6 & 16359.61 & .75 & 1505.96 & 31547663.87 & 478.69 \\
\hline \multirow{3}{*}{$\begin{array}{l}\text { Most Extreme } \\
\text { Differences }\end{array}$} & Absolute & .139 & .185 & .115 & .222 & .152 & .208 & .270 & .112 \\
\hline & Positive & .139 & .141 & .096 & .222 & .148 & .208 & .270 & .112 \\
\hline & Negative & -.090 & -.185 & -.115 & -.182 & -.152 & -.157 & -.205 & -.066 \\
\hline \multicolumn{2}{|c|}{ Kolmogorov-Smimov Z } & 1.358 & 1.808 & 1.119 & 2.167 & 1.483 & 2.027 & 2.636 & 1.096 \\
\hline \multicolumn{2}{|c|}{ Asymp. Sig. (2-tailed) } & .050 & .003 & .164 & .000 & .025 & .001 & .000 & .181 \\
\hline
\end{tabular}

a. Test distribution is Normal.

b. Calculated from data.

\section{ANNEX VI: RESULTS OF MULTICOLLINEARITY TEST}

\begin{tabular}{r|cc} 
Variable & VIF & $1 /$ VIF \\
\hline Intangible s & 1.62 & 0.617758 \\
Assets & 1.52 & 0.656081 \\
Cashflow & 1.29 & 0.775853 \\
DPS & 1.17 & 0.856266 \\
MarketCapi n & 1.15 & 0.871080 \\
\hline Mean VIF & 1.08 & 0.922164 \\
\hline
\end{tabular}




\section{ANNEX VII: RESULTS OF HAUSMAN TEST}

- hausman fixed random

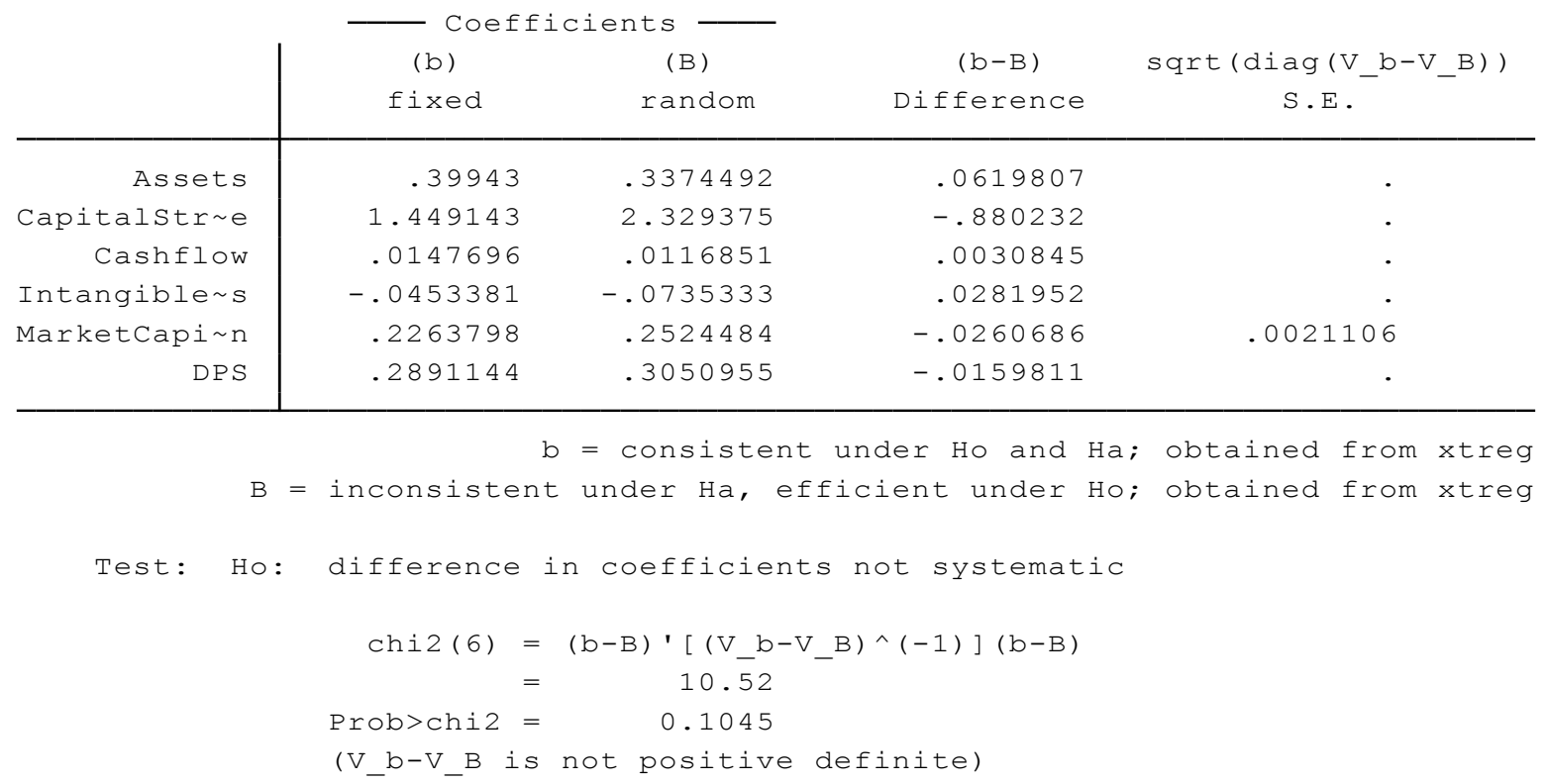

\section{(cc) $\overline{E Y}$}

This work is licensed under a Creative Commons Attribution 3.0 License. 